\title{
DOES THE SELFISH LIFE-CYCLE MODEL APPLY IN THE CASE OF JAPAN?
}

\author{
Charles Yuji Horioka
}

March 2020

The Institute of Social and Economic Research Osaka University 


\title{
Does the Selfish Life-Cycle Model Apply in the Case of Japan?
}

\author{
Charles Yuji Horioka \\ (Research Institute for Economics and Business Administration, Kobe University; \\ Asian Growth Research Institute; Institute of Social and Economic Research, Osaka \\ University; and National Bureau of Economic Research)
}

March 2020

\begin{abstract}
In this paper, we first provide a brief exposition of the simplest version of the selfish life cycle model or hypothesis, which is undoubtedly the most widely used theoretical model of household behavior in economics, and then survey the literature on household saving behavior in Japan (with emphasis on the author's own past research) to shed light on whether or not the selfish life-cycle model applies in the case of Japan. In particular, we survey the literature on the impact of the age structure of the population on the saving rate, the saving behavior of retired households, saving motives, the prevalence of bequests, bequest motives, tests of altruism, and the importance of borrowing (liquidity) constraints and show that almost all of the available evidence suggests that the selfish life-cycle model applies to a greater extent in Japan than it does in other countries. Finally, we discuss the policy implications of our findings.
\end{abstract}

Keywords: Age structure of the population; aged; altruism; bequests; bequest motives; borrowing constraints; consumption; dissaving; elderly; estates; household behavior; household saving; households; inheritances; intergenerational transfers; Japan; lifecycle hypothesis; life-cycle model; life-cycle theory; liquidity constraints; old age; retirees; saving; saving motives; selfishness

Journal of Economic Literature (JEL) classification codes: D11, D12, D14, D15, D64, E21, J14

Address for correspondence: Charles Yuji Horioka, Research Institute for Economics and Business Administration, Kobe University, 2-1, Rokkodai-cho, Nada-ku, Kobe, Hyogo 657-8501, JAPAN. Email: horioka@rieb.kobe-u.ac.jp 


\section{Introduction}

The selfish life-cycle model or hypothesis is undoubtedly the most widely used theoretical model of household behavior in economics. Many researchers have investigated whether or not this model applies in the case of Western economies, and the broad consensus is that it does (see, for example, Modigliani (1975), Deaton (1992, 2005), Hayashi (1997b), and Attanasio (1999), and Jappelli and Pistaferri (2017)), but whether or not it applies in Japan and other non-Western economies with very different traditions, social norms, and institutions and closer family ties is another question. The purpose of this paper is to survey the literature on household saving behavior in Japan (with emphasis on the author's own past research) to shed light on whether or not the selfish life-cycle model applies in the case of Japan. There have been many comprehensive surveys of the literature on household saving and consumption behavior in Japan (for example, Hayashi (1986, 1997a), Horioka (1984, 1990, 1993, 2008a), and Ogawa and Horioka (1996)), but this paper is unique in that it focuses on the question of whether or not the selfish life-cycle model applies in the case of Japan.

To preview the main findings of this paper, virtually all of available evidence suggests that the selfish life-cycle model applies to a greater extent in Japan than in other countries. Thus, the answer to the question posed in the title of this paper is an unqualified "yes."

This paper is organized as follows: I provide a brief exposition of the simplest version of the selfish life-cycle model in section 2; I survey the literature on the impact of the age structure of the population on the saving rate in section 3 , that on the saving behavior of the retired elderly in section 4, that on saving motives in section 5, that on the prevalence of bequests in section 6 , that on bequest motives in section 7, that on tests of altruism in section 8 , and that on the importance of borrowing constraints in section 9; and I summarize my findings and discuss the policy implications thereof in section 10 .

\section{The Selfish Life-Cycle Model}

In this section, we provide a brief exposition of the simplest version of the selfish lifecycle model, which is primarily attributable to Franco Modigliani and his collaborators for more details, see Modigliani and Brumberg (1954) and Modigliani (1966)). In order to simplify the model as much as possible, we ignore the childhood years and assume that individuals graduate from school and start working at age 0 and that they work from age 0 until age $\mathrm{R}$, earning $\mathrm{Y}$ yen each year, part of which they use to finance their current consumption and part of which they save in preparation for their retirement years. We further assume that individuals retire at age $\mathrm{R}$, that they finance their living expenses during retirement by drawing down their previously accumulated savings, and that they die with certainty at age L. Finally, we assume that individuals smooth their consumption throughout their lives, consuming $\mathrm{C}$ yen per year from age 0 until age $\mathrm{L}$, and that they are selfish, receiving no bequests or inter vivos transfers from their parents and leaving no bequests or inter vivos transfers to their children (see Figure 1). 
If we assume that the interest rate is zero, these assumptions imply that lifetime income will be $\mathrm{Y}^{*} \mathrm{R}$ and that lifetime consumption will be $\mathrm{C}^{*} \mathrm{~L}$. Thus, the lifetime budget constraint can be expressed as follows:

$$
\mathrm{Y} * \mathrm{R}=\mathrm{C} * \mathrm{~L}
$$

If equation (1) is solved for $\mathrm{C}$, we can obtain the following expression for $\mathrm{C}$, which denotes the annual amount of consumption:

$$
\mathrm{C}=(\mathrm{R} / \mathrm{L})^{*} \mathrm{Y}
$$

In words, consumption will be a constant fraction of income, with that fraction being equal to the ratio of one's working years to total lifespan.

SW, the annual saving of working individuals can be calculated by subtracting consumption $\mathrm{C}$ from income $\mathrm{Y}$ and substituting the expression in equation (2) for $\mathrm{C}$ :

$$
\mathrm{SW}=\mathrm{Y}-\mathrm{C}=(1-\mathrm{R} / \mathrm{L}) * \mathrm{Y}=((\mathrm{L}-\mathrm{R}) / \mathrm{L}) * \mathrm{Y}
$$

In words, the saving of working individuals will be a constant fraction of their income, with that fraction being equal to the ratio of their retirement span to total lifespan.

Moreover, since individuals are assumed to work for R years, CSW, the cumulative saving of working individuals, is as follows:

$$
\mathrm{CSW}=\mathrm{R}^{*}((\mathrm{~L}-\mathrm{R}) / \mathrm{L}) * \mathrm{Y}=(\mathrm{L}-\mathrm{R}) *(\mathrm{R} / \mathrm{L})^{*} \mathrm{Y}
$$

As for retired individuals, since they have no income but need to consume, their consumption will be financed entirely by drawing down their previously accumulated saving. Thus, SR, the annual (dis)saving of retired individuals, is as follows:

$$
\mathrm{SR}=-\mathrm{C}=-(\mathrm{R} / \mathrm{L}) * \mathrm{Y}
$$

Moreover, since the retirement span of retired individuals is $(\mathrm{L}-\mathrm{R})$ years, CSR, the cumulative (dis)saving of retired individuals, is as follows:

$$
\mathrm{CSR}=-(\mathrm{L}-\mathrm{R}) *(\mathrm{R} / \mathrm{L}) * \mathrm{Y}
$$

As can be seen by comparing equations (4) and (6), the cumulative saving of working individuals and the cumulative (dis)saving of retired individuals are precisely equal to one another in absolute magnitude but have opposite signs. This confirms that the lifetime budget constraint of individuals is satisfied. This is the same as saying that the area of the rectangle showing the cumulative saving of individuals during their working years is exactly equal to the area of the rectangle showing the cumulative (dis)saving of individuals during their retirement years in Figure 1. 
Next, I wish to derive the saving amount and saving rate of the household sector as a whole. From equations (3) and (5), AS, the aggregate saving of the household sector as a whole, is as follows:

$$
\mathrm{AS}=\mathrm{POP}(0, \mathrm{R}) *((\mathrm{~L}-\mathrm{R}) / \mathrm{L}) * \mathrm{Y}-\mathrm{POP}(\mathrm{R}, \mathrm{L}) *(\mathrm{R} / \mathrm{L}) * \mathrm{Y},
$$

where $\operatorname{POP}(0, R)=$ the population aged 0 to $R$ (the working-age population) $\operatorname{POP}(\mathrm{R}, \mathrm{L})=$ the population aged $\mathrm{R}$ to $\mathrm{L}$ (the retirement-age population)

Furthermore, AY, the aggregate income of the household sector as a whole, is as follows:

$$
\mathrm{AY}=\mathrm{POP}(0, \mathrm{R})^{*} \mathrm{Y}
$$

Thus, ASY, the saving rate of the household sector as a whole, is as follows:

$$
\mathrm{ASY}=\mathrm{AS} / \mathrm{AY}=(\mathrm{L}-\mathrm{R}) / \mathrm{L}-[\mathrm{POP}(\mathrm{R}, \mathrm{L}) / \mathrm{POP}(0, \mathrm{R})]^{*}(\mathrm{R} / \mathrm{L})
$$

In other words, the saving rate of the household sector as a whole should be a function of the ratio of the retirement-age population to the working-age population, and the higher is this ratio, the lower should be the household saving rate. Moreover, the derivative of the household saving rate with respect to this ratio should equal the negative of the ratio of one's working years to total lifespan.

Thus, we can test whether the selfish life-cycle model applies by examining whether or not the age structure of the population (in particular, the ratio of the retirement-age population to the working-age population) has the expected impact on the household saving rate.

Thus far, we have simplified our theoretical model by making the following assumptions:

(1) There is no economic growth.

(2) There is no public old-age pension system.

(3) There is no lifespan uncertainty.

The age structure of the population will have an impact on the household saving rate even if these simplifying assumptions are relaxed, but what will change is that now other factors will also affect the household saving rate.

(1) If the economy is growing, cohorts born later will have higher lifetime incomes than cohorts born earlier, and thus the aggregate saving of cohorts that are working and saving will exceed the aggregate (dis)saving of cohorts that are retired and dissaving. As a result, if the economy is growing, the aggregate saving of the household sector as a whole will be positive, and the higher is the economic growth rate, the greater will be the aggregate saving of the household sector as a whole. 
(2) If a public old-age pension system is introduced, there will be less need to save in preparation for one's retirement years, and thus one would expect the saving of working-age individuals and the (dis)saving of retired individuals to be less than in a world with no public old-age pension system (see Feldstein (1974)).

(3) If lifespan is uncertain and individuals are risk-averse, one would expect the saving of working-age individuals to be greater and the dissaving of retirement-age individuals to be less than in a world with no lifespan uncertainty because individuals will be afraid of running out of money before they die (see Davies (1981)). This will lead individuals to leave unintended or accidental bequests unless they are able to completely annuitize their wealth.

\section{Evidence on the Impact of the Age Structure of the Population on the Saving Rate}

We showed in the previous section that, if the selfish life-cycle model applies, the household saving rate should be a decreasing function of the ratio of the retirement-age population to the working-age population. Thus, we can shed light on the applicability of the selfish life-cycle model by investigating whether or not the age structure of the population has the expected impact on the saving rate.

The author has used a variety of data sources to investigate the impact of the age structure of the population on the saving rate, and in this section, we survey this body of work and consider whether or not the findings are consistent with the selfish life-cycle model. In subsection 3.1, we discuss papers that make use of cross-section data, while in subsection 3.2, we discuss papers that make use of time-series data.

\subsection{Evidence based on Cross-Country Data}

Horioka $(1986,1989)$ uses data on the member countries of the Organisation for Economic Co-operation and Development (OECD) for the 1975-84 period from the OECD to analyze the determinants of the private saving rate and finds that the ratio of the retirement-age population to the working-age population has a negative and statistically significant impact on the private saving rate.

Based on his estimation results, Horioka $(1986,1989)$ calculates the contribution of each factor to the difference between Japan's private saving rate and the OECD-wide average and to the U.S.-Japan saving rate gap (see Table 1). During the 1975-84 time period, Japan's population was the youngest and her retirement-age population to working-age population ratio was the lowest among all OECD member countries at the time, and as Table 1 shows, this can explain virtually all of the difference between Japan's private saving rate and the OECD-wide average and about half of the U.S.-Japan saving rate gap.

Similarly, Horioka and Terada-Hagiwara (2012) use panel data on twelve Asian countries for the 1966-2007 period from Penn World Tables to analyze the determinants 
of the domestic saving rate, and as in the case of Horioka $(1986,1989)$, they find that the ratio of the retirement-age population to the working-age population has a negative and statistically significant impact on the domestic saving rate.

Finally, Horioka and Wan (2007) use provincial panel data for the 1995-2004 period from a household survey to analyze the determinants of the household saving rate in China and find that the impact of the ratio of the retirement-age population to the working-age population is negative, as expected, but often not statistically significant.

\subsection{Evidence based on Time-Series Data}

Horioka (1997) uses time-series data for the 1955-93 period from Japan's National Accounts to analyze the determinants of Japan's household saving rate and finds that there is a cointegrating relationship between the household saving rate and the ratio of the retirement-age population to the working-age population and that this ratio has a negative and statistically significant impact on the household saving rate.

Figure 2 shows trends over time in National Accounts data on Japan's household saving rate for the 1955-2018 period, and as can be seen from this figure, Japan's household saving rate showed a sharp upward trend from 1955 until the mid-1970s, peaking at $23.2 \%$, and showed a sharp downward trend thereafter, sometimes even becoming negative.

The ratio of the retirement-age population to the working-age population in Japan has shown a steady upward trend over time so Horioka's (1997) finding that this ratio has a negative and statistically significant impact on the household saving rate implies that the upward trend in this ratio can explain the downward trend in Japan's household saving rate since the mid-1970s and that further increases in this ratio will cause further declines in Japan's household saving rate in future years (see Horioka $(1989,1992)$ ).

\subsection{Summary}

In this section, we showed that the ratio of the retirement-age population to the workingage population has a negative and statistically significant impact on the saving rate whether one uses cross-country data or time-series data. This not only suggests that the selfish life-cycle model applies in the case of Japan but also that the low ratio of the retirement-age population to the working-age population can explain why Japan's household saving rate was so high in the past and that the sharp increase in this ratio can explain the sharp decline in Japan's household saving rate since the mid-1970s. Thus, the selfish life-cycle model can explain the level of, as well as trends over time in, Japan's household saving rate.

\section{Evidence on the Saving Behavior of Retirees}

The selfish life-cycle model assumes that working individuals save and that retirees dissave. Thus, we can shed light on the applicability of the selfish life-cycle model by 
examining the saving behavior or retirees. In this section, we survey studies that examine the saving behavior of retirees and consider whether or not they are consistent with the selfish life-cycle model.

Hayashi, et al. (1988) carefully analyze household-level data from the "National Survey of Family Income and Expenditure," which is conducted every five years by the Statistics Bureau of the Japanese Ministry of Internal Affairs and Communications and find that the elderly start dissaving after the age of 80 whether they live in nuclear households or extended (three-generation) households. However, Hayashi, et al. (1988) do not take account of the employment status of respondents, and if they had confined the sample to retired elderly, they are likely to have found that the Japanese elderly start dissaving at an earlier age.

Horioka $(2006,2010)$ and Horioka and Niimi (2017) analyze tabulated data on retired elderly from the "Family Income and Expenditure Survey," which is conducted by the Statistic Bureau of the Japanese Ministry of Internal Affairs and Communications, and find that the saving rate of such households has fluctuated in the -40 to $-10 \%$ range and that their decumulation rate of financial assets has fluctuated in the 1 to $3 \%$ range since 2000. ${ }^{1}$ These findings constitute convincing evidence that Japanese retirees are dissaving and strongly suggest that the selfish life-cycle model applies in the case of Japan (see also Horioka, et al. (1996), Horioka and Niimi (2017), and Niimi and Horioka (2019)).

\section{Evidence on Saving Motives}

The simplest version of the selfish life-cycle model implies that individuals should be saving primarily for living expenses during retirement and that they should not be saving to leave bequests to their children. Thus, we can shed light on the applicability of the selfish life-cycle model by looking at the relative importance of saving for individual motives. In this section, we survey studies that attempt to estimate the contribution of saving for each motive to total household saving and consider whether or not the findings are consistent with the selfish life-cycle model.

Let me first explain the methodology for calculating the amount of saving for each motive. If individuals cannot realize a motive with only their current income, they need to rely on saving. Moreover, at any given time, there will be individuals who are saving in order to prepare for a given motive as well as individuals who are dissaving to realize the same motive. For example, at any given time, there will be pre-retirement individuals who are saving for retirement as well as post-retirement individuals who are dissaving for retirement. Thus, the contribution that saving for a given motive makes to aggregate household saving is net saving for that motive, which can be calculated as gross saving

\footnotetext{
${ }^{1}$ Horioka and Niimi (2017) and Niimi and Horioka (2019) point out that the rate of wealth decumulation of Japanese retirees is slower than one might expect but show that this can be explained by the presence of precautionary saving and bequest motives, especially the former. See Ventura and Horioka (2019) for a similar analysis of the determinants of the saving behavior of retirees in Italy.
} 
for that motive minus dissaving for that motive. Mathematically,

$$
\mathrm{NS}=\text { net saving for a given motive }=\mathrm{GS}-\mathrm{DS}
$$

where GS = gross saving for a given motive

$\mathrm{DS}=$ dissaving for a given motive

Furthermore, there are two ways in which one can use saving to help realize a given motive. The first way is to rely on one's own wealth, and in the case of this way, one accumulates the financial assets needed to realize the motive in question beforehand and draws down those assets in order to realize that motive. The other way is to rely on borrowing, and in this case, one borrows the funds needed to realize the motive in question, uses those funds to realize that motive, and repays the loan little by little after realizing the motive (note that loan repayments (repayment of the principal) are a form of saving). What should be noted is that the saving is done before the realization of the motive when one relies on one's own wealth and that it is done after the realization of the motive when one relies on borrowing.

The gross saving and dissaving for a given motive in the case of the two financing methods are shown in Table 2, and as can be seen from this table, the gross saving for a given motive equals the sum of saving in the form of the accumulation of financial assets and saving in the form of loan repayments. Similarly, dissaving for a given motive equals dissaving in the form of the decumulation of financial assets and dissaving in the form of new borrowings. Moreover, as noted earlier, net saving for a given motive equals gross saving for that motive minus dissaving for that motive.

In 1996, the former Institute of Posts and Telecommunications Policy of the Japanese conducted the "U.S.-Japan Comparison Survey of Saving" simultaneously in the United States and Japan, and this survey collected detailed information on saving, dissaving, new borrowings, and loan repayments for each motive. Horioka, et al. $(1998,2000)$ use the data from this survey to calculate the contribute of saving for each motive to aggregate household saving (see Horioka (1988) and Horioka and Watanabe (1997, 1998) for a similar analysis using data on Japan from a different source).

Table 3 shows data from Horioka, et al. $(1998,2000)$ on the contribution of net saving for each motive to total household saving. If the selfish life-cycle model applies, individuals should be saving primarily for the retirement motive, and as this table shows, net saving for the retirement motive accounts for a full $62.23 \%$ and $30.84 \%$ of total household saving in Japan and the United States, respectively, and that it is by far the dominant component of household saving in both countries. Thus, the selfish life-cycle model seems to apply in both countries. However, the share of retirement-related saving in Japan is more than twice what it is in the United States, which suggests that the selfish life-cycle model applies to a greater extent in Japan than it does in the United States. ${ }^{2}$

${ }^{2}$ The second most important saving motive is the precautionary motive in both countries. 
If the simplest version of the selfish life-cycle model applies, individuals should not leave a bequest to their children and should therefore not be saving in order to leave a bequest. As can be seen from Table 3, the share of net saving for the bequest motive is $1.50 \%$ in Japan and $5.04 \%$ in the United States, and thus its share is low in both countries but especially in Japan. Thus, our findings concerning saving for the bequest motive also suggest that the selfish life-cycle model applies in both Japan and the United States but that it is especially applicable in the case of Japan.

To summarize, our findings concerning saving motives also suggest that the selfish lifecycle model applies to a greater extent in Japan than in other countries.

\section{Evidence on the Prevalence of Bequests}

The simplest version of the selfish life-cycle model assumes that individuals do not leave any bequests or other intergenerational transfers to their children so we can shed light on the applicability of the selfish life-cycle model by looking at the prevalence of bequests and other transfers. In this section, we survey the literature on the prevalence of bequests and other transfers and consider whether or not the findings are consistent with the selfish life-cycle model.

The most commonly used measure of the importance of bequests and other intergenerational transfers is the share of such transfers in total household wealth. This measure was first used by Kotlikoff and Summers (1981), and they obtain the shocking result that the share of intergenerational transfers in total household wealth amounts to a full 46 to 81 percent. Subsequently, many researchers have calculated this share using a variety of methodology and data sources for a large number of countries. Davies and Shorrocks (2000) survey this literature and conclude that the majority of studies find that this share is 35 to $45 \%$ in the United States, roughly comparable to the United States in Canada, and somewhat higher in France.

Moreover, a number of researchers have tried to calculate the share of intergenerational transfers in total household wealth for the case of Japan. For example, Hayashi (1986) estimates this share to be at least 9\%, Dekle (1989) estimates it to be 3-49\%, Barthold and Ito (1992) estimate it to be at most 25-40\%, Campbell (1997) estimates it to be 23$28 \%$, and Horioka (2008b,c and 2009) estimates it to be $15-18 \%$. Thus, this share appears to be lower in Japan than it is in the United States and other countries, which suggests that bequests and other intergenerational transfers are less important quantitatively in Japan than they are in other countries. Thus, the findings concerning the quantitative importance of bequests also suggest that the selfish life-cycle model applies to a greater extent in Japan than in other countries.

Another approach for gauging the importance of bequests and other intergenerational transfers is to look not at the amounts of bequests actually left but to ask individuals about their bequest intentions. Osaka University has been conducting a household survey called the "Preference Parameters Study" in four countries (China, India, Japan, and the United States) since 2003, and fortunately, this survey contains several questions about 
bequests. The bequest data from this survey are analyzed in detail in Horioka (2014a,b), and as can be seen from these papers, the proportion of respondents planning to leave a bequest to their children is by far the highest in India (87.05\%), also relatively high in the United States $(60.77 \%)$ and China $(56.35 \%)$, and by far the lowest in Japan $(31.44 \%)$. These findings reinforce our earlier conclusion that bequests are less prevalent in Japan than in other countries and that the selfish life-cycle model applies to a greater extent in Japan than in other countries.

\section{Evidence on Bequest Motives}

In the previous section, we presented our findings concerning the prevalence of bequests and other intergenerational transfers and concluded that they are less prevalent in Japan than in other countries. However, even if the selfish life-cycle model applies, individuals may still leave bequests and other transfers, and thus, even if we find that individuals do leave bequests and other transfers, we cannot make a determination about the applicability of the selfish life-cycle model unless we know the reasons for which individuals leave bequests and other transfers. Thus, in this section, we present evidence on the motives for which individuals leave bequests and other transfers and consider whether or not the findings are consistent with the selfish life-cycle model.

If individuals are selfish, as assumed by the life-cycle model, they should either leave no bequests at all, leave only accidental or unintentional bequests arising from lifespan uncertainty, or selfish motivated bequests. One example of selfishly motivated bequests is the strategic (or exchange) bequest motive proposed by Bernheim, Shleifer, and Summers (1985), according to which parents leave a bequest to their children to induce them to provide care, attention, and/or financial assistance during old age. By contrast, altruistic parents will leave a bequest to their children unconditionally (i.e., whether or not their children provide anything in return) (see Arrondel and Masson (2006) and Laferrère and Wolff (2006)). Thus, we can shed light on the applicability of the selfish life-cycle model by looking at data on bequest motives.

The "Preference Parameters Study" of Osaka University that we referred to in the previous section collects information on bequest motives in four countries (China, India, Japan, and the United States). The survey asks "How do you feel about leaving an inheritance to your children?" and respondents are asked to select one of eight options. Two of the eight options ("I plan to leave an inheritance to my child(ren) no matter what" and "I do not plan to leave an inheritance to my child(ren) under any circumstances because doing so may reduce their will to work") are altruistic, while four ("I plan to leave an inheritance to my child(ren) only if they provide care (including nursing care) during old age," "I plan to leave an inheritance to my child(ren) only if they provide financial assistance during old age," "I do not plan to make special efforts to leave an inheritance to my child(ren) but will leave whatever is left over," and "I do not plan to leave an inheritance to my child(ren) under any circumstances because I want to use my wealth myself") are selfish.

Horioka $(2014 \mathrm{a}, \mathrm{b})$ presents data on bequest motives from this survey for China, India, 
Japan, and the United States, and as can be seen from these papers, the proportion of respondents with an altruistic bequest motive is highest in India (75.80\%) and also very high in the United States (66.97\%), whereas this proportion is lowest in Japan (33.98\%) and also relatively low in China (37.40\%). By contrast, the proportion of respondents with a selfish bequest motive is highest in Japan $(64.96 \%)$ and also relatively high in China (55.10\%), whereas this proportion of lowest in India $(21.82 \%)$ and also relatively low in the United States (32.76\%). Thus, judging from the evidence on bequest motives, the Japanese are the most selfish among the four peoples and the Chinese are the next most selfish, whereas Indians are the most altruistic and Americans are the next most altruistic. $^{3}$

Moreover, as the data presented in Horioka (2014a) show, data on bequest division point to the same conclusion (i.e., that the Japanese are the most selfish and the Chinese the second most selfish). However, in the case of bequest division, Americans and Indians change positions, with Americans being the most altruistic and Indians being the second most altruistic.

Thus, not only do the Japanese leave fewer bequests than other peoples but their bequests are more selfishly motivated that those of other peoples. These findings strongly suggest that the selfish life cycle model applies to a greater extent in Japan than in other countries.

\section{Evidence from Tests of Altruism}

The simplest version of the selfish life-cycle model assumes that individuals are selfish, not altruistic, so we can shed light on the applicability of this model by conducting tests of altruism. Thus, in this section, we survey papers that have conducted tests of altruism and consider whether or not their findings are consistent with the selfish life-cycle model.

First, we survey the literature that examines the impact of parental bequest motives on the behavior of children. If children are altruistic, they should provide care, attention, and financial assistance to their parents regardless of whether or not they expect to receive bequests from their parents. Conversely, if children are selfish, they should provide care, attention, and financial assistance to their children only if they expect to receive bequests from their parents (Bernheim, Shleifer, and Summers's (1985) strategic bequest motive).

(1) Ohtake and Horioka (1994) find that the housing assets of parents have a positive and statistically significant impact on the probability that their children live with them, and the financial net worth of parents has a positive and statistically significant impact on the amount of the financial assistance children provide to their parents.

(2) Komamura (1994) finds that the housing assets of parents have a positive and

\footnotetext{
${ }^{3}$ See Horioka, et al., (1998), Horioka, et al. (2000), Horioka (2002a,b), Horioka (2008b,c), and Horioka (2009) for similar data from other surveys.
} 
statistically significant impact on the probability that their children live with them.

(3) Yamada (2006) finds that whether or not children expect to inherit a house from their parents has a positive and statistically significant impact on the probability that their children live with them and on the frequency with which their children contact them and a negative and statistically significant impact on the distance between their own home and their children's home.

(4) Wakabayashi and Horioka (2009) find that whether or not parents are managers or homeowners has a positive and statistically significant impact on the probability that their children live with them.

(5) Kohara and Ohtake (2011) find that the educational attainment of parents has a positive and statistically significant impact on the probability that their children take care of them during old age.

(6) Horioka, et al. (2018) find that whether or not children expect to receive a bequest from their parents has a positive and statistically significant impact on the probability that they live with or near their parents and on the probability that they help their parents with housework.

If parental assets, homeownership, occupation, and educational attainment are regarded as proxies for expected bequests from parents, all of the aforementioned findings suggest that the probability receiving bequests from parents and/or the expected amount of such bequests have a positive and statistically significant impact on the probability of parents living with, or near, their children and on the probability of receiving care, attention, and/or financial assistance from their children. This in turn suggests that the Japanese are selfish, not altruistic.

Laferrère and Wolff (2006) survey the literature from throughout the world on the impact of parental bequests on children's behavior. They find that such research is the most prevalent in the United States and that two-thirds of such studies for the United States suggest that Americans are altruistic (see also Horioka (2014a)). Thus, our findings in this section are consistent with our earlier conclusion in section 7 that the Japanese are more selfish than Americans.

Moreover, Hayashi (1995) conducts a completely different test of altruism using Japanese data. If parents and children are both altruistic, the two sides should pool their incomes when deciding how much to consume, and thus if one controls for the combined income of parents and children, parental income or children's income should not have any impact on total consumption. However, Hayashi (1995) finds, even after controlling for combined income by introducing fixed effects, that parental income and children's income have a statistically significant impact on total consumption. This suggests that the Japanese are not pure altruists. 
Thus, tests of altruism suggest that Japanese individuals are selfish, not altruistic, and that the selfish life-cycle model applies in the case of Japan.

\section{Evidence on the Importance of Borrowing (Liquidity) Constraints}

In our brief exposition of the selfish life-cycle model in section 2 , we assumed that individuals smooth their consumption over their lifetimes, but this result requires that capital markets are perfect and that borrowing (liquidity) constraints do not exist. Thus, we can shed light on the applicability of the selfish life-cycle model by looking at how important borrowing (liquidity) constraints are in the real world. In this section, we survey the literature on the importance of borrowing (liquidity) constraints in Japan and consider whether or not the findings are consistent with the selfish life-cycle model.

Hayashi (1985) and Watanabe, Watanabe, and Watanabe (2001) find that about 15\% and $25 \%$ of Japanese households face borrowing (liquidity) constraints, respectively. Similarly, Kohara and Horioka (2006) find that 8 to 15\% of young Japanese couples are borrowing (liquidity) constrained. Thus, all previous studies suggest most Japanese households are not borrowing (liquidity) constrained and that the selfish life-cycle model applies in the case of Japan. ${ }^{4}$

Moreover, Horioka (2012a, b) and Horioka and Niimi (2020) find that the ratio of household liabilities to household disposable income in Japan was the highest among the Group of Seven (G7) countries until at least 2005

All of these findings suggest that borrowing (liquidity) constraints are not so important in Japan and provide further evidence that the selfish life-cycle model applies in the case of Japan.

\section{Conclusion and Policy Implications}

In this paper, we first provided a brief exposition of the simplest version of the selfish life cycle model or hypothesis, which is undoubtedly the most widely used theoretical model of household behavior in economics, and then surveyed the literature on household saving behavior in Japan (with emphasis on the author's own past research) to shed light on whether or not the selfish life-cycle model applies in the case of Japan. In particular, we surveyed the literature on the impact of the age structure of the population on the saving rate, the saving behavior of retired households, saving motives, the prevalence of bequests, bequest motives, tests of altruism, and the importance of borrowing (liquidity) constraints and show that almost all of the available evidence suggests that the selfish life-cycle model applies to a greater extent in Japan than it does in other countries. Thus, the answer to the question posed in the title of this paper is an

\footnotetext{
${ }^{4}$ However, Ogawa (2007) finds that the proportion of households facing borrowing (liquidity) constraints has increased sharply since the mid-1990s.
} 
unqualified "yes."

Needless to say, selfish behavior and altruistic behavior coexist in all countries, and Japan is no exception. Fumio Hayashi, the foremost authority on Japanese saving behavior, concludes his survey paper on this topic as follows (Hayashi (1997a), p. 322):

"We can now profitably contemplate what sort of model is best suited for explaining these stylized facts [about Japanese household saving behavior]. It has become clear that intergenerational linkages through the exchange of nonmarket services and through altruism will be an essential ingredient."

Moreover, Hayashi makes the following assertion elsewhere in the same paper (Hayashi(1997a), p. 319): "[b]oth the exchange and altruistic motives are important for explaining [Japanese household saving behavior]."

The current author agrees completely with Hayashi but strongly feels that selfish behavior is more prevalent in Japan than altruistic behavior and that the selfish life-cycle model applies to a considerable extent in the case of Japan.

Some readers may be surprised to learn that the selfish life-cycle model applies to a greater extent in Japan than in the United States and other countries because Japan is a non-Western country with very different traditions, social norms, and institutions and closer family ties. However, it must be borne in mind that the fact that family ties are close does not necessarily imply that family members harbor feelings of altruism toward one another. It could be that family ties are more extensive than in other countries but that they are motivated by strategic rather than altruistic considerations (see Horioka (2019) for a more extensive discussion of the impact of culture on the saving and bequest behavior of the Japanese).

Finally, I would like to consider the policy implication of my finding that the selfish lifecycle model applies in the case of Japan. This conclusion has at least five important implications:

(1) When constructing theoretical models to describe Japanese household behavior, one should construct models that assume that households are selfish rather than altruistic or models that assume that selfish households and altruistic households coexist.

(2) As population aging progresses even further in Japan, Japan's household saving rate can be expected to decline ever further. This is likely to lead to substantial capital shortages, which in turn may necessitate fiscal reconstruction measures designed to reduce the large deficits (negative saving) of the government sector.

(3) Ricardian equivalence does not apply in the case of Japan, meaning that the Japanese Government will be able to stimulate the economy by implementing tax cuts that are financed by the issuance of government bonds (Barro, 1974). 
(4) Our finding that bequests are motivated primarily by strategic or exchange considerations in Japan implies that they are accompanied by some sort of quid pro quo such as care, attention, and financial assistance during old age. This, in turn, implies that bequests in Japan will be largely offset by transfers in the opposite direction (from children to parents), meaning that net transfers from parents to children will not necessarily be large or even positive and that wealth disparities will not necessarily be transmitted from generation to generation (from parents to children). ${ }^{5}$

(5) Our finding that bequests are motivated primarily by strategic or exchange considerations in Japan implies that the introduction of a public long-term care insurance system in 2000 may lead to a reduction in the prevalence of bequests because parents will no longer need to rely on their children for care during old age to the same extent as in the past.

Thus, whether or not the selfish life-cycle model applies in the case of Japan is important not only from an intellectual perspective but also from a policy perspective, and thus further work on this topic is of urgent need. I am therefore planning to continue my research on this topic as I enter the retirement phase of my life cycle.

\section{Acknowledgements}

This paper is based in large part on my keynote lecture at the Annual Meeting of the Society of Economics of the Household (SEHO), my keynote lecture at the International Conference on Business, Economics and Finance, School of Business and Economics, Universiti Brunei Darussalam, Brunei, my invited lecture at the Singapore Economic Review Conference (SERC), my special lecture at the Autumn Meeting of the Japanese Economic Association (JEA), and Horioka (2020). I am grateful to Yuichi Abiko, Shoshana Grossbard, Kazuo Ogawa, Ryosuke Okamoto, Etsuro Shioji, Takashi Unayama, and other participants of these conferences, especially Yoko Niimi, for their valuable comments. This work was supported by JSPS (Japan Society for the Promotion of Science) KAKENHI Grant Numbers $18 \mathrm{H} 00870$ and $15 \mathrm{H} 05728$.

\footnotetext{
${ }^{5}$ However, Niimi and Horioka (2018) find that individuals receiving bequests are more likely to leave bequests, which suggests that there is a danger than wealth disparities will be passed on from parents to children.
} 


\section{References}

Arrondel, Luc, and Andre Masson (2006), “Altruism, Exchange or Indirect Reciprocity: What Do the Data on Family Transfers Show?" in Handbook of the Economics of Giving, Altruism and Reciprocity, vol. 2, edited by Serge-Christophe Kolm and Jean Mercier Ythier, Elsevier Science B.V., Amsterdam, Netherlands: 971-1053.

Attanasio, Orazio P. (1999), "Consumption," Handbook of Macroeconomics, vol. 1, part B, edited by John B. Taylor and Michal Woodford, Elsevier, New York, NY: 741-812.

Barro, Robert J. (1974), “Are Government Bonds Net Wealth?” Journal of Political Economy, 82(6): 1095-1117.

Barthold, Thomas A., and Takatoshi Ito (1992), "Bequest Taxes and Accumulation of Household Wealth: U.S.-Japan Comparison," in The Political Economy of Tax Reform, edited by Takatoshi Ito and Anne Krueger, University of Chicago Press, Chicago, IL: 235-290.

Bernheim, B. Douglas, Andrei Shleifer, and Lawrence H. Summers (1985), "The Strategic Bequest Motive," Journal of Political Economy, 93(6): 1045-1076.

Campbell, David (1997), "Transfer and Life-cycle Wealth in Japan, 1974-1984," Japanese Economic Review, 48(4): 410-423.

Davies, James B. (1981), "Uncertain Lifetime, Consumption, and Dissaving in Retirement," Journal of Political Economy, 89(3): 561-577.

Davies, James B., and Anthony F. Shorrocks (2000), "The Distribution of Wealth," in Handbook of Income Distribution, vol. 1, edited by Anthony B. Atkinson and Francois Bourguignon, Elsevier Science B. V., Amsterdam, Netherlands: 605-675.

Deaton, Angus (1992), Understanding Consumption, Clarendon Press, Oxford, UK.

Deaton, Angus (2005), "Franco Modigliani and the Life Cycle Theory of Consumption," Banca Nazionale del Lavoro Quarterly Review, 58(233-234): 91-107.

Dekle, Robert (1989), "The Unimportance of Intergenerational Transfers in Japan," Japan and the World Economy, 1(4): 403-413.

Feldstein, Martin (1974), "Social Security, Induced Retirement, and Aggregate Capital Accumulation," Journal of Political Economy, 82(5): 905-926.

Hayashi, Fumio (1985), "The Permanent Income Hypothesis and Consumption Durability: Analysis based on Japanese Panel Data," Quarterly Journal of Economics, 100(4): 1083-1113.

Hayashi, Fumio (1986), “Why Is Japan's Saving Rate So Apparently High?” in NBER Macroeconomics Annual 1986, vol. 1, MIT Press, Cambridge, MA: 147-210.

Hayashi, Fumio (1995), "Is the Japanese Extended Family Altruistically Linked? A Test Based on Engel Curves," Journal of Political Economy, 103(3): 661-674.

Hayashi, Fumio (1997a), "Introduction to Part III: A Review of Recent Literature on Japanese Saving," in Understanding Saving: Evidence from the United States and Japan, edited by Fumio Hayashi, MIT Press, Cambridge, MA: 289-329.

Hayashi, Fumio (1997b), Understanding Saving, MIT Press, Cambridge, MA.

Hayashi, Fumio, Albert Ando, and Richard Ferris (1988), "Life Cycle and Bequest Savings: A Study of Japanese and U.S. Households based on Data from the 1984 NSFIE and the 1983 Survey of Consumer Finances," Journal of Japanese and International Economies, 2(4): 450-491.

Horioka, Charles Yuji (1984), "The Applicability of the Life-Cycle Hypothesis of Saving to Japan," Kyoto University Economic Review, 54(2): 31-56. 
Horioka, Charles Yuji (1986), "Why Is Japan's Private Savings Rate So High?” Finance and Development, 23(4): 22-25.

Horioka, Charles Yuji (1988), "Saving for Housing Purchase in Japan," Journal of the Japanese and International Economies, 2(3): 351-384.

Horioka, Charles Yuji (1989), "Why Is Japan's Private Saving Rate So High?" in Developments in Japanese Economics, edited by Ryuzo Sato and Takashi Negishi, Academic Press/Harcourt Brace Jovanovich, Tokyo, Japan: 145-178.

Horioka, Charles Yuji (1990), "Why Is Japan's Household Saving Rate So High? A Literature Survey," Journal of the Japanese and International Economies, 4(1): 4992.

Horioka, Charles Yuji (1992), "Future Trends in Japan's Saving Rate and the Implications Thereof for Japan's External Imbalance," Japan and the World Economy, 3(4): 307-330.

Horioka, Charles Yuji (1993), "Saving in Japan," in World Savings: An International Survey, edited by Arnold Heertje, Blackwell Publishers, Oxford, UK: 238-278.

Horioka, Charles Yuji (1997), "A Cointegration Analysis of the Impact of the Age Structure of the Population on the Household Saving Rate in Japan," Review of Economics and Statistics, 79(3): 511-516.

Horioka, Charles Yuji (2002a), "Are the Japanese Selfish, Altruistic, or Dynastic?" Japanese Economic Review, 53(1): 26-54.

Horioka, Charles Yuji (2002b), "Nihonjin ha Rikotekika, Ritatekika, Ouchoutekika (Are the Japanese Selfish, Altruistic, or Dynastic?)" Gendai Keizaigaku no Chouryuu (Trends in Contemporary Economics), edited by Keijiro Otsuka, Miko Nakayama, Shin-ichi Fukuda, and Yuzou Honda, Toyo Keizai Shinposha, Tokyo, Japan: 23-45 (in Japanese).

Horioka, Charles Yuji (2006), "Do the Elderly Dissave in Japan?" in Long-Run Growth and Short-Run Stabilization: Essays in Memory of Albert Ando, edited by Lawrence R. Klein, Edward Elgar Publishing, Cheltenham, UK: 129-136.

Horioka, Charles Yuji (2008a), "A Survey of Household Saving Behaviour," in The Demographic Challenge--A Handbook about Japan, edited by Florian Coulmas, Harald Conrad, Annette Schad-Seifert, and Gabriele Vogt, Brill Academic Publishers, Leiden, Netherlands: 879-897.

Horioka, Charles Yuji (2008b), "Isan to Kakusa (Bequests and Inequality)," Kikan Shakai Hoshou Kenkyuu, 44(3): 307-315 (in Japanese).

Horioka, Charles Yuji (2008c), "Nihon ni okeru Isan Douki to Oyako Kankei: Nihonjin ha Rikotekika, Ritatekika, Ouchoutekika (Bequest Motives and Parent-Child Relations in Japan: Are the Japanese Selfish, Altruistic, or Dynastic?)," Setainai Bunpai / Sedaikan Iten no Keizai Bunseki (Economic Analysis of Intra-household Distribution and Intergenerational Transfers), edited by Charles Yuji Horioka and Institute for Research on Household Economics, Minerva Shobo, Kyoto, Japan: 118135 (in Japanese).

Horioka, Charles Yuji (2009), "Do Bequests Increase or Decrease Wealth Inequalities?" Economics Letters, 103(1): 23-25.

Horioka, Charles Yuji (2010), "The (Dis)saving Behavior of the Aged in Japan," Japan and the World Economy, 22(3): 151-158.

Horioka, Charles Yuji (2012a), "Are Japanese Households Financially Healthy, If So, Why?" Japanese Economy, 39(4): 109-124. 
Horioka, Charles Yuji (2012b), "Japan and the Western Model: An Economist's View of Cultures of Household Finance," in The Development of Consumer Credit in Global Perspective: Business, Regulation, and Culture, edited by Jan Logemann, Palgrave Macmillan, London, UK: 243-256.

Horioka, Charles Yuji (2014a), "Are Americans and Indians More Altruistic than the Japanese and Chinese? Evidence from a New International Survey of Bequest Plans," Review of Economics of the Household, 12(3): 411-437.

Horioka, Charles Yuji (2014b), "Naze Hitobito ha Isan wo Nokosunoka? Aijou kara nanoka, Rikoshin kara nanoka? Isan Douki no Kokusai Hikaku (Who Do People Leave Bequests? Is It Out of Love or Selfishness? An International Comparison of Bequest Motives," Higashi Ajia no Shiten, 25(4), pp. 51-62 (in Japanese).

Horioka, Charles Yuji (2019), "Are the Japanese Unique? Evidence from Household Saving and Bequest Behavior," Singapore Economic Review, 64(1): 5-22.

Horioka, Charles Yuji (2020), "Nihon de Raifu Saikuru Kasetsu ha Naritatteiruka? (Is the Life Cycle Hypothesis Applicable in Japan?)" in Gendai Keizaigaku no Choryuu (Trends in Contemporary Economics), edited by Japanese Economic Association, Toyo Keizai Shinposha, Tokyo, Japan, forthcoming (in Japanese).

Horioka, Charles Yuji; Hideki Fujisaki, Wako Watanabe, and Shouhei Ishibashi (1998), "Chochiku Douki / Isan Douki no Nichibei Hikaku (A U.S.-Japan Comparison of Saving Motives and Bequest Motives)," Nichibei Kakei no Chochiku Koudou, edited by Charles Yuji Horioka and Koji Hamada, Nihon Hyoronsha, Tokyo, Japan: 71-111 (in Japanese).

Horioka, Charles Yuji, Hideki Fujisaki, Wako Watanabe, and Takatsugu Kouno (2000), "Are Americans More Altruistic than the Japanese? A U.S.-Japan Comparison of Saving and Bequest Motives," International Economic Journal, 14(1): 1-31.

Horioka, Charles Yuji, Emin Gahramanov, Aziz Hayat, and Xueli Tang (2018), "Why Do Children Take Care of Their Elderly Parents? Are the Japanese Any Different?" International Economic Review, 59(1): 113-136.

Horioka, Charles Yuji, Norihiro Kasuga, Katsuyo Yamazaki, and Wako Watanabe (1996), "Do the Aged Dissave in Japan? Evidence from Micro Data," Journal of the Japanese and International Economies, 10(3): 295-311.

Horioka, Charles Yuji, and Yoko Niimi (2017), "Nihon no Koureisha Setai no Chochiku Koudou ni kansuru Jisshou Bunseki (An Empirical Analysis of the Saving Behavior of Elderly Households in Japan)," Keizai Bunseki, 196: 29-47 (in Japanese).

Horioka, Charles Yuji, and Yoko Niimi (2020), "Household Debt and Aging in Japan," in Remaking Retirement: Debt in an Aging Economy, edited by Olivia S. Mitchell and Annamaria L. Lusardi, Oxford University Press, Oxford, UK, forthcoming.

Horioka, Charles Yuji, and Akiko Terada-Hagiwara (2012), "The Determinants and Long-term Projections of Saving Rates in Developing Asia," Japan and the World Economy, 24(2): 128-137.

Horioka, Charles Yuji, and Junmin Wan (2007), "The Determinants of Household Saving in China: A Dynamic Panel Analysis of Provincial Data," Journal of Money, Credit and Banking, 39(8): 2077-2096.

Horioka, Charles Yuji, and Wako Watanabe (1997), "Why Do People Save? A MicroAnalysis of Motives for Household Saving in Japan," Economic Journal, 107(442): 537-552.

Horioka, Charles Yuji, and Wako Watanabe (1998), "Nihonjin no Mokuteki-betsu 
Chochiku-gaku: 1994-nen no 'Kakei ni okeru Kin'yuu Shisan Sentaku ni kansuru Chousa' kara no Maikuro Deta wo Mochiita Suikei (Saving Amounts by Motive of the Japanese: Estimates based on Micro Data from the 1994 'Survey of Financial Asset Choice of Households')," Nichibei Kakei no Chochiku Koudou, edited by Charles Yuji Horioka and Koji Hamada, Nihon Hyoronsha, Tokyo, Japan: 29-69 (in Japanese).

Jappelli, Tullio, and Pistaferri, Luigi (2017), The Economics of Consumption: Theory and Evidence, Oxford University Press, Oxford, UK.

Kohara, Miki, and Charles Yuji Horioka (2006), "Do Borrowing Constraints Matter? An Analysis of Why the Permanent Income Hypothesis Does Not Apply in Japan," Japan and the World Economy, 18(4): 358-377.

Kohara, Miki, and Fumio Ohtake (2011), "Altruism and the Care of Elderly Parents," Japanese Economy, 38(2): 3-18.

Komamura, Kouhei (1994), "Koreisha Kakei ni okeru Isan Koudou no Keizai Bunseki (An Economic Analysis of Bequest Behavior in Elderly Households)," Kikan Shakai Hoshou Kenkyuu, 30(1): 62-74 (in Japanese).

Kotlikoff, Laurence J., and Lawrence H. Summers (1981), "The Role of Intergenerational Transfers in Aggregate Capital Accumulation," Journal of Political Economy, 89(4): 706-732.

Laferrère, Anne, and Francois-Charles Wolff(2006), "Microeconomic Models of Family Transfers," in Handbook of the Economics of Giving, Altruism and Reciprocity, vol. 2, edited by Serge-Christophe Kolm and Jean Mercier Ythier, Elsevier Science B.V., Amsterdam, Netherlands: 889-969.

Modigliani, Franco (1966), "The Life Cycle Hypothesis of Saving, the Demand for Wealth and the Supply of Capital," Social Research, 33(2): 160-217.

Modigliani, Franco (1975), "The Life-cycle Hypothesis of Saving Twenty Years Later," Contemporary Issues in Economics, edited by Michael Parkin, Manchester University Press, Manchester, UK: 2-35.

Modigliani, Franco, and Richard H. Brumberg (1954), "Utility Analysis and the Consumption Function: An Interpretation of Cross-section Data," Post-Keynesian Economics, edited by Kenneth K. Kurihara, Rutgers University Press, New Brunswick, NJ: 388-436

Niimi, Yoko, and Charles Yuji Horioka (2018), "The Impact of Intergenerational Transfers on Wealth Inequality in Japan and the United States," World Economy, 41(8): 2042-2066.

Niimi, Yoko, and Charles Yuji Horioka (2019), "The Wealth Decumulation Behavior of the Retired Elderly in Japan: The Relative Importance of Precautionary Saving and Bequest Motives," Journal of the Japanese and International Economies, 51: 52-63.

Ogawa, Kazuo (2007), "Why Did Japan's Household Savings Rate Fall in the 1990s" Applied Economics, 39(18): 2341-2353.

Ogawa, Kazuo, and Charles Yuji Horioka (1996), "Shouhi / Chochiku (Consumption and Saving)," in Nihon Keizai Jiten (Japanese Economic Encyclopedia), edited by Keimei Kaizuka, Yutaka Kousai, and Yuujirou Nonaka, Nihon Keizai Shinbunsha, Tokyo, Japan: 965-980 (in Japanese).

Ohtake, Fumio, and Charles Yuji Horioka (1994), "Chochiku Douki (Saving Motives)," Nihon no Shotoku to Tomi no Bunpai (The Distribution of Income and Wealth in Japan), edited by Tsuneo Ishikawa, Tokyo Daigaku Shuppankai, Tokyo, Japan: 211- 
244 (in Japanese).

Ventura, Luigi, and Charles Yuji Horioka (2019), "The Wealth Decumulation Behavior of the Retired Elderly in Italy: The Importance of Bequest Motives and Precautionary Saving," mimeo., Research Institute for Economics and Business Administration, Kobe University, Nada-ku, Kobe, Japan,

Wakabayashi, Midori, and Charles Yuji Horioka (2009), "Is the Eldest Son Different? The Residential Choice of Siblings in Japan," Japan and the World Economy, 21(4): 337-348.

Watanabe, Katsunori, Takayuki Watanabe, and Tsutomu Watanabe (2001), "Tax Policy and Consumer Spending: Evidence from Japanese Fiscal Experiments," Journal of International Economics, 53(2): 261-281.

Yamada, Ken (2006), "Intra-family Transfers in Japan: Intergenerational Co-residence, Distance, and Contact," Applied Economics, 38(16): 1839-1861. 
Figure 1: The Selfish Life-Cycle Model

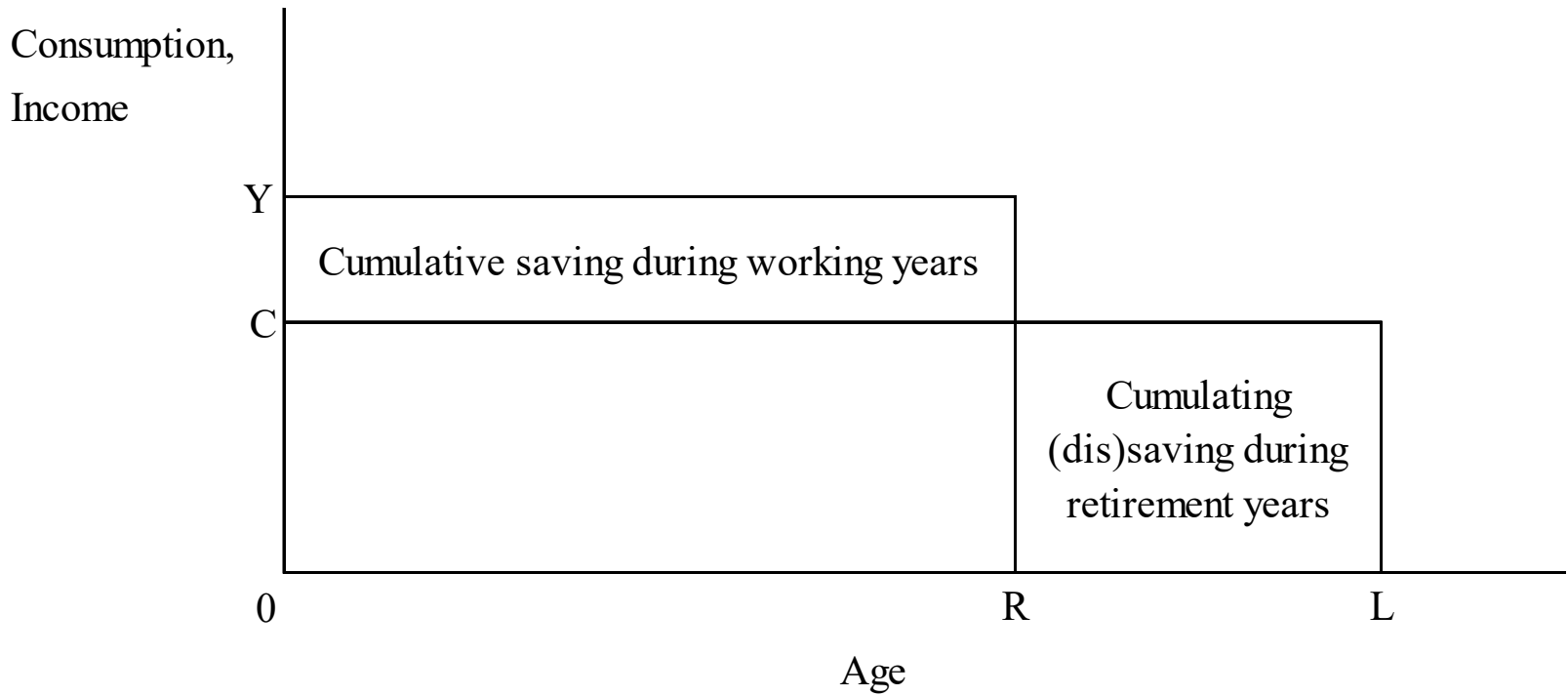

Table 1: A Decomposition of the Private Saving Rate Gap between Japan and Other Countries

\begin{tabular}{|l|c|c|}
\hline \multicolumn{1}{|c|}{ Factor } & $\begin{array}{c}\text { U.S.-Japan } \\
\text { gap }\end{array}$ & $\begin{array}{c}\text { Gap between } \\
\text { Japan and } \\
\text { OECD-wide } \\
\text { average }\end{array}$ \\
\hline The contribution of a high income growth rate & +0.45 & +0.47 \\
\hline The contribution of a low retirement-age population ratio & +5.45 & +6.90 \\
\hline The contribution of a low dependent-age population ratio & +1.64 & +1.07 \\
\hline $\begin{array}{l}\text { The contribution of a high labor force participation rate of the } \\
\text { elderly }\end{array}$ & -3.94 & -3.89 \\
\hline The contribution of a low per capita income level & +4.36 & +1.29 \\
\hline Subtotal & +7.96 & +5.85 \\
\hline Unexplained residual & +2.90 & +0.95 \\
\hline Total private saving rate gap & +10.86 & +6.80 \\
\hline
\end{tabular}

Note: The figures denote the contribution of each factor to the private saving rate gap (in percentage points).

Source: Horioka (1986, 1989) 
Figure 2: Trends over Time in Japan's Household Saving Rate, 1955-2018

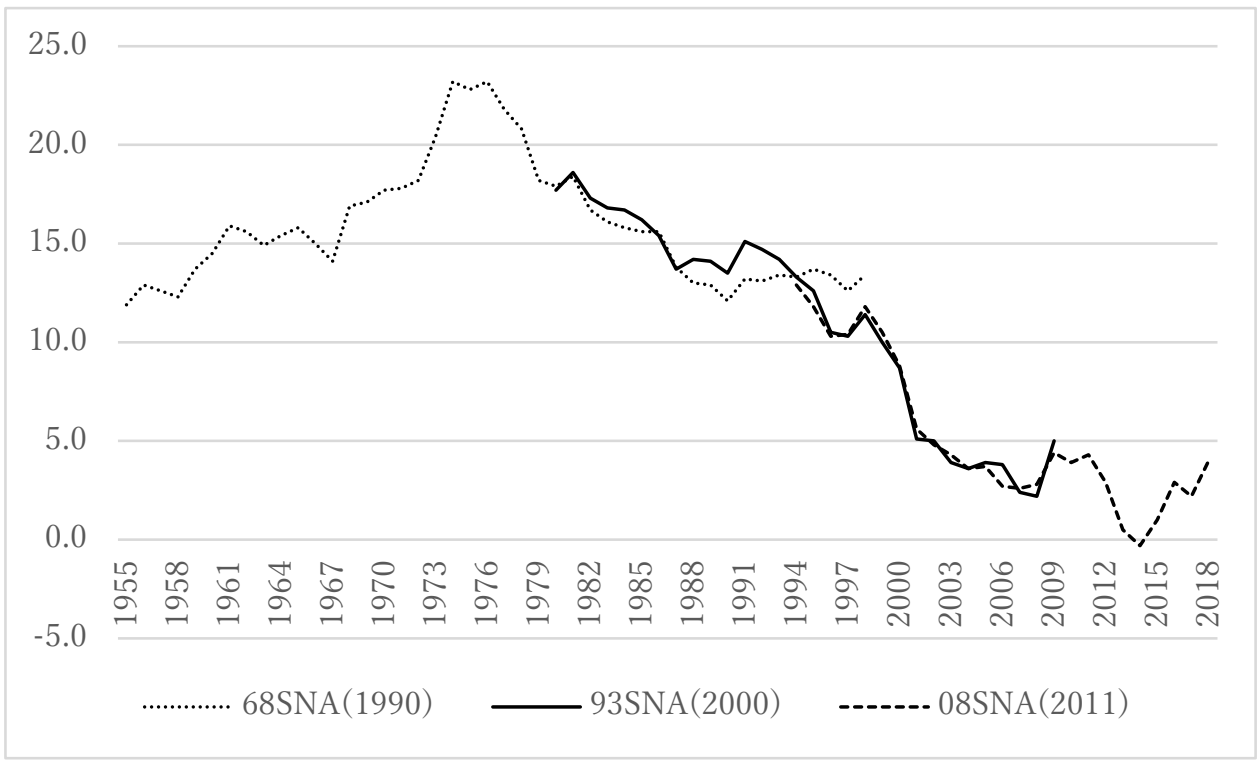

Note: This figure shows trends over time in the household saving rate, which is defined as household saving as a share of household disposable income (in percent).

Source: Economic and Social Research Institute, Cabinet Office, Government of Japan, "Annual Report on National Accounts," various issues.

Table 2: Saving for Specific Motives

\begin{tabular}{l|c|c}
\hline Financing method & Gross saving & Dissaving \\
\hline Own wealth & $\begin{array}{c}\text { Accumulation of financial } \\
\text { assets }\end{array}$ & $\begin{array}{c}\text { Decumulation of financial } \\
\text { assets }\end{array}$ \\
\hline Borrowing & Loan repayments & New borrowing \\
\hline
\end{tabular}


Table 3: A U.S.-Japan Comparison of the Share of Net Saving for Each Motive

\begin{tabular}{|l|r|r|}
\hline \multicolumn{1}{|c|}{ Saving Motive } & Japan & U.S. \\
\hline Retirement & 62.23 & 30.84 \\
\hline Precautionary & 41.18 & 27.93 \\
\hline Children's education & 8.77 & -0.14 \\
\hline Children's marriage & 7.31 & 2.87 \\
\hline Housing purchase & -15.57 & 14.60 \\
\hline Consumer durable purchases & 1.54 & 4.20 \\
\hline Leisure & 2.44 & 6.35 \\
\hline Payment of taxes & 0.25 & 6.40 \\
\hline Independent business & -0.37 & 2.59 \\
\hline Bequests & 1.50 & 5.04 \\
\hline Other & -9.29 & -0.66 \\
\hline Total & 100.00 & 100.00 \\
\hline
\end{tabular}

Note: The figures denote the share of net saving for each motive in total household saving (in percent).

Source: Horioka, et al. (1998) and Horioka, et al. (2000). 